\title{
Does financial inclusion reduce non-performing loans and loan loss provisions?
}

\author{
Peterson K. Ozili ${ }^{\mathrm{a}, *}$, Ahmed Adamu ${ }^{\mathrm{b}}$ \\ a Central Bank of Nigeria, Abuja, Nigeria \\ Nile University of Nigeria, Abuja, Nigeria \\ b Nile University of Nigeria, Abuja, Nigeria.
}

\begin{abstract}
A B S T R A C T
We examine whether countries that have high levels of financial inclusion have fewer non-performing loans and loan loss provisions in their banking sectors. The fixed effect panel regression methodology was used to analyse the effect of financial inclusion on bank non-performing loans and loan loss provisions. Using data from 48 countries, we find that greater formal account ownership is associated with high non-performing loans. Bank loan loss provisions are fewer in countries that have high levels of financial inclusion only when financial inclusion is achieved through the combined use of formal account ownership, bank branch supply and ATM supply. Also, non-performing loans are fewer in countries that experience economic boom and high levels of financial inclusion.
\end{abstract}

\author{
A R T I C L E I N F O \\ Keywords: \\ financial inclusion, non-performing \\ loans, loan loss provisions, financial \\ stability, bank stability, ATM, formal \\ account ownership.

\section{*Corresponding author:} \\ petersonkitakogelu@yahoo.com \\ (Dr Peterson K. Ozili) \\ Article history: \\ Received 30.05.2021 \\ Revised: 25.07.2021 \\ Accepted 19.08.2021 \\ DOI: \\ https://doi.org/10.51410/jcgirm.8.2.2
}

\section{INTRODUCTION}

In this paper, we examine whether financial inclusion reduces the size of non-performing loans and loan loss provisions in the banking sector. We examine whether countries that have high levels of financial inclusion have fewer non-performing loans and fewer loan loss provisions in their banking sectors.

Financial inclusion involves bringing unbanked adults into the formal financial sector (Allen et al, 2016; Ozili, 2020). Financial inclusion is a strategy towards economic development especially for the excluded population. Many countries have taken deliberate steps to increase the level of financial inclusion. There is much research on the benefits of financial inclusion to individuals, firms and households (Subbarao, 2009; Allen 2016; Ozili, 2018).

Existing studies show that financial inclusion has some positive benefits for financial institutions (see, Han and Melecky, 2013; García and José, 2016; Ozili, 2018). Only few studies examine the effect of 
financial inclusion on bank non-performing loans while existing studies have not examined the effect of financial inclusion on bank loan loss provisions.

In the literature, some studies suggest that financial inclusion can improve financial stability by increasing the deposit base of banks, the number of financial institutions and financial instruments (see, Hannig and Jansen, 2010; Han and Melecky, 2013; García and José, 2016). But these studies did not examine the effect of financial inclusion on crucial indicators of bank stability such as non-performing loans and loan loss provisions. This paper addresses this gap in the literature.

Non-performing loans are important indicators of bank soundness and stability (Nkusu, 2011). Loan loss provision is also an important indicator of bank safety from a prudential regulatory perspective (Ozili, 2021c). Bank supervisors require banks to reduce the size of non-performing loans (Boudriga et al, 2009), and to keep sufficient loan loss provisions to mitigate their credit risk exposure (Ozili, 2017). Understanding how financial inclusion affects bank stability is important because it can help bank regulators to understand the contribution of financial inclusion to the overall soundness of the banking sector.

This study contributes to the banking literature. It shows that financial inclusion is a determinant of bank stability. In the paper, we estimate the effect of several measures of financial inclusion on bank nonperforming loans and loan loss provisions. We find some evidence that financial inclusion, together with some macroeconomic conditions, improves bank stability by reducing the size of non-performing loans and loan loss provisions in the banking sector.

This study also contributes to studies that examine the consequence of financial inclusion. It shows that greater formal account ownership is associated with high non-performing loans, but the use of formal accounts together with other financial indicators lowers the size of loan loss provisions.

The rest of the paper is structured as follows. Section 2 presents the literature review and hypotheses. Section 3 presents the research design, including the data, model and variable justification. Section 4 reports and discuss the results. Section 5 concludes.

\section{LITERATURE REVIEW AND HYPOTHESIS DEVELOPMENT}

Some studies examine how bank behavior or activities affect financial inclusion. For instance, Léon and Zins (2020) examine whether the development of regional foreign banks increase financial inclusion for firms and households. They use African bank data. They find that the presence of regional foreign banks increases firms' access to credit. Owen and Pereira (2018) examine the association between financial PAGE 11| Journal of Corporate Governance, Insurance, and Risk Management | 2021, VOL. 8, Series. 2 
inclusion and banking structure in a cross country analysis. They use several indicators of financial inclusion and banking structure. Their results show that greater banking industry concentration is associated with more access to deposit accounts and loans. They also find that financial inclusion is higher in countries in which regulations allow banks to engage in a broader scope of activities.

Other studies examine whether financial inclusion affects bank performance and stability. Kumar et al (2021) examine whether financial inclusion increases bank profitability. They analyse 122 Japanese banks from 2004 to 2018. They find that a reduction in the number of bank branches reduces the profitability of Japanese banks. However, increase in the number of loan accounts and automated teller machines (ATMs) did not have a significant effect on bank profitability. Musau et al (2018) analyse the effect of financial inclusion on credit risk in Kenya. Credit risk was measured using the non-performing loan ratio. They analyse 43 commercial banks in Kenya from 2007 to 2015. They find that bank availability, bank accessibility and bank usage had a significant effect on credit risk of commercial banks in Kenya. Ahamed and Mallick (2019) examine the association between financial inclusion and bank stability. They undertake a cross-country study of 2635 banks in 86 countries from 2004 to 2012. They find that higher levels of financial inclusion have a positive association with bank stability. The positive association is pronounced for (i) banks that have higher customer deposit funding share, (ii) banks that have lower marginal costs of providing banking services, and (iii) banks that operate in countries with stronger institutional quality.

In a separate study, Chauvet and Jacolin (2017) investigate the impact of financial inclusion on bank performance. They analyse 55,596 firms in 79 countries. They find that financial inclusion has a positive impact on firm growth. The positive impact is magnified when banking markets are less concentrated. Ozili (2021a), in a cross country analysis, examine whether high levels of financial inclusion are associated with greater financial risk in the banking sector. Financial risk was measured using the nonperforming loan ratio and cost to income ratio. The results show that higher formal account ownership is associated with higher non-performing loan and high cost inefficiency in the financial sector of developed countries, advanced countries and transition economies. They also find that the combined use of credit cards with increased formal account ownership reduced insolvency risk and improved financial sector efficiency in developing countries.

Markose et al (2020) examine the economic viability of the Prime Minister Jan-Dhan Yojna (PMJDY) financial inclusion scheme introduced in India. They examine whether the scheme is economically viable in terms of the supply side funding gaps that threaten the efficacy and sustainability of the scheme. They analyse the PMDJY data for public sector banks, private sector banks and regional banks from 2014 to 2017. They found a lack of economic viability of PMJDY accounts in the majority of Indian public sector banks due to the rising cost which public sector banks have to bear to sustain the scheme. PAGE 12| Journal of Corporate Governance, Insurance, and Risk Management | 2021, VOL. 8, Series. 2 
Muthia et al (2019) examine the effect of financial inclusion on bank efficiency in Indonesia. They examine 26 banks in Indonesia from 2011 to 2016. They find that financial inclusion has a positive and significant effect on bank efficiency. Chen et al (2018) examine whether the promotion of financial inclusion affects the non-performing loans of commercial banks in China. They analyse data from 31 provinces from 2005 to 2016. The results reveal a negative impact of financial inclusion on nonperforming loans.

To date, the literature has not examined the effect of financial inclusion on loan loss provisions, particularly how bank loan loss provisions are affected by supply-side financial inclusion instruments such as increase in bank branches and ATM supply. The present study fills this gap in the literature.

\subsection{Hypothesis development}

There are two main predictions for the effect of financial inclusion on non-performing loans and loan loss provisions. The first prediction is that greater financial inclusion may lead to high non-performing loans when loans are given to risky individuals, households and businesses (Musau et al, 2018). Loans granted to these risky segment of the population may not be repaid. When the loans are not repaid, it will increase the non-performing loans of banks and subsequently increase the size of loan loss provisions. When this is the case, we predict that greater financial inclusion will increase nonperforming loans and loan loss provisions in the banking sector.

H1: greater financial inclusion is associated with higher non-performing loans and loan loss provisions in the banking sector.

On the other hand, greater financial inclusion can provide an opportunity for banks to diversify their loan portfolio to a diverse set of customers. Such loan diversification helps to reduce credit risk that arises from an undiversified loan portfolio. It will also reduce credit risk that arises from over-lending to a small group of customers which increases concentration risk in the loan portfolio of banks. When the loan portfolio is well diversified, it will not only prevent loans from being concentrated around a narrow group of borrowers, it will also increase the customer base of banks, and provide an opportunity for banks to diversify their loan portfolio thereby reducing concentration risk and credit risk in bank lending. The reduced credit risk will lead to fewer non-performing loans, and subsequently a reduction in the size of bank loan loss provisions. When this is the case, we predict that financial inclusion will reduce the size of non-performing loans and loan loss provisions. The findings of Morgan and Pontines (2014) supports this prediction. They find that an increase in lending to small and medium-sized enterprises reduces the non-performing loans of financial institutions. 
H2: greater financial inclusion is associated with fewer bank non-performing loans and fewer loan loss provisions in the banking sector.

\section{RESEARCH DESIGN}

\subsection{Data}

The data used in this study was extracted from the global financial development indicators and the world development indicators available in the World Bank database. The dataset covers 48 countries. The countries are reported in table 1. The sample period covers only three years: 2011, 2014 and 2017. This narrow period was selected based on data availability as financial inclusion data was available mostly for the year 2011, 2014 and 2017. Countries that did not have reported data for financial inclusion, nonperforming loans and loan loss provisions were removed from the sample, leaving only countries that have the required data in the sample.

\subsection{The Model}

The econometric model used to estimate the effect of financial inclusion on non-performing loans and loan loss provisions is specified below. The model is estimated using the fixed effect regression estimation procedure.

$$
\begin{aligned}
\text { LLPi, } t=c+ & \beta 1 A C C i, t+\beta 2 B R i, t+\beta 3 A T M i, t+\beta 4 N P L i, t+\beta 5 G D P i, t \\
& + \text { ei,t } \ldots . . \text { equation } 1
\end{aligned}
$$

where ' $c$ ' is the constant term, ' $\mathrm{i}$ ' is country, and ' $\mathrm{t}$ ' is year. 'ACC' is the number of adults that own an account at a formal financial institution (\% age 15+). 'ATM' is the number of automated teller machines (ATMs) per 100,000 adults. 'BR' is the number of bank branches per 100,000 adults. 'NPL' is the bank non-performing loans to gross loans ratio (\%). 'LLP' is loan loss provisions divided by gross loans (\%). This ratio is derived by multiplying the NPL ratio with the LLC ${ }^{1}$ ratio. 'GDP' is real GDP growth rate.

\subsection{Variable justification}

The ACC, BR and ATM variables are the financial inclusion indicators used in this study. Formal account ownership (ACC), bank branches per 100,000 adults (BR) and ATMs per 100,000 adults (ATM)

\footnotetext{
${ }^{1}$ LLC is the loan loss coverage ratio. It is expressed as loan loss provisions divided by non-performing loans.
}

PAGE 14| Journal of Corporate Governance, Insurance, and Risk Management | 2021, VOL. 8, Series. 2 
are widely used as indicators of financial inclusion in the financial inclusion literature (see, Naumenkova et al, 2019; Raza et al, 2019; Ozili, 2020; Neaime and Gaysset, 2018; Ozili, 2018; Emara and El Said, 2021, Kumar et al, 2021; and Ozili, 2021b).

A financial inclusion index (AFI) variable was also introduced into the model during our additional test. The AFI variable was derived as the average of the sum of three financial inclusion variables (i.e. ACC, BR and ATM). We do not have a definite prediction for the impact of financial inclusion on loan loss provisions and non-performing loan.

In the loan loss provisions model in equation 1, the NPL variable controls for the impact of nonperforming loans on loan loss provisions. The literature show that non-performing loan is a major nondiscretionary determinant of loan loss provisions in the banking sector (see Ozili and Outa, 2017; Caporale et al, 2018; Danisman et al, 2021). Many studies report a positive relationship between loan loss provisions and non-performing loans because banks will increase loan loss provisions when they expect high non-performing loans. This expectation is consistent with Bhat et al (2019) and Peterson and Arun (2018). Therefore, a positive relationship between loan loss provisions and non-performing loans is expected.

The GDP variable used in the study is real GDP growth rate. The GDP variable controls for the impact of macroeconomic changes on loan loss provisions. The literature shows that real GDP growth, which captures the state of the economy, affects the size of loan loss provisions (see, Floro, 2010; Pool et al, 2015). In times of economic prosperity, loan loss provisions are fewer in the banking sector because debtors can easily repay their debt as their incomes increase and business profit increase. This leads to fewer non-performing loans and fewer loan loss provisions. In recessionary times, loan loss provisions are higher in the banking sector due to tight financial conditions that make it difficult for debtors to repay their debt owed to banks. This leads to higher non-performing loans and higher loan loss provisions (see, Peterson and Arun, 2018; Ozili and Outa, 2017). Therefore, a negative relationship between GDP and LLP is expected.

\section{RESULTS}

\subsection{Descriptive statistics and correlation}

The descriptive statistics result is reported in table 1 . The mean values for each country is reported. Bank branch per 100,000 adults (BR) is highest in Spain and Bulgaria, and much lower in Peru and the Philippines. Formal account ownership (ACC) is highest in Denmark, Sweden and Australia, and much lower in Moldova and El Salvador. Automated Teller Machine (ATM) supply is highest in Australia and Austria and much lower in India. Loan loss provisions ratio (LLP) is highest in Brazil, and much lower in Canada. Non-performing loans ratio (NPL) is highest in Cyprus and Ukraine, and much lower in Canada. Real GDP growth rate (GDP) is highest in Turkey, and much lower in Ukraine.

PAGE 15| Journal of Corporate Governance, Insurance, and Risk Management | 2021, VOL. 8, Series. 2 
Table 1: Country-specific descriptive statistics (mean values)

\begin{tabular}{|c|c|c|c|c|c|c|c|}
\hline & ACC & ATM & BR & NPL & LLP & GDP & AFI \\
\hline Albania & 35 & 33 & 22 & 18 & 93 & 2 & 30 \\
\hline Argentina & 43 & 41 & 13 & 1 & 154 & 2 & 32 \\
\hline Armenia & 26 & 55 & 21 & 5 & 34 & 5 & 34 \\
\hline Australia & 99 & 165 & 29 & 1 & 25 & 2 & 98. \\
\hline Austria & 97 & 154 & 14 & 2 & 67 & 2 & 88 \\
\hline Belarus & 70 & 50 & 1 & 7 & 45 & 3 & 40 \\
\hline Belgium & 97 & 90 & 39 & 3 & 48 & 1 & 75 \\
\hline Bosnia & 55 & 46 & 32 & 12 & 91 & 1 & 44 \\
\hline Brazil & 64 & 114 & 19 & 3 & 165 & 1 & 66 \\
\hline Bulgaria & 62 & 93 & 56 & 14 & 74 & 2 & 71 \\
\hline Canada & 98 & 219 & 22 & 0.6 & 21 & 2 & 113 \\
\hline Colombia & 37 & 38 & 15 & 3 & 164 & 4 & 30 \\
\hline Costa Rica & 60 & 65 & 22 & 1 & 123 & 3 & 49 \\
\hline Croatia & 86 & 122 & 34 & 13 & 74 & 0.8 & 81 \\
\hline Cyprus & 88 & 57 & 47 & 31 & 83 & 1 & 64 \\
\hline Czech & 81 & 49 & 22 & 4 & 55 & 2 & 51 \\
\hline Denmark & 99 & 55 & 29 & 3 & 51 & 1 & 61 \\
\hline Ecuador & 44 & 30 & 11 & 3 & 123 & 4 & 28 \\
\hline El Salvador & 25 & 33 & 12 & 2 & 122 & 2 & 23 \\
\hline Estonia & 97 & 77 & 13 & 2 & 32 & 5 & 62 \\
\hline Georgia & 44 & 65 & 29 & 3 & 66 & 5 & 46 \\
\hline Greece & 83 & 65 & 30 & 31 & 97 & -2 & 59 \\
\hline Guatemala & 35 & 31 & 33 & 2 & 68 & 3 & 33 \\
\hline Hungary & 73 & 58 & 15 & 11 & 76 & 3 & 49 \\
\hline India & 55 & 16 & 12 & 5 & 51 & 6 & 28 \\
\hline Indonesia & 34 & 40 & 16 & 2 & 59 & 5 & 30 \\
\hline Ireland & 94 & 92 & 23 & 16 & 65 & 6 & 69 \\
\hline Latvia & 91 & 64 & 23 & 7 & 91 & 4 & 59 \\
\hline Malaysia & 77 & 50 & 10 & 1 & 31 & 5 & 46 \\
\hline Mexico & 33 & 48 & 14 & 2 & 165 & 2 & 32 \\
\hline Moldova & 26 & 33 & 38 & 13 & 79 & 5 & 32 \\
\hline North Macedonia & 74 & 55 & 24 & 8 & 124 & 2 & 51 \\
\hline Panama & 38 & 58 & 22 & 2 & 50 & 7 & 39 \\
\hline Paraguay & 26 & 23 & 9 & 2 & 96 & 4 & 19 \\
\hline Peru & 30 & 65 & 7 & 3 & 129 & 3 & 34 \\
\hline Philippines & 28 & 22 & 8 & 2 & 72 & 5 & 20 \\
\hline Russia & 63 & 155 & 34 & 7 & 85 & 2 & 84 \\
\hline Saudi Arabia & 62 & 66 & 8 & 1 & 159 & 4 & 45 \\
\hline Singapore & 97 & 62 & 9 & 1 & 38 & 4 & 56 \\
\hline Slovak & 80 & 57 & 26 & 4 & 63 & 2 & 54 \\
\hline Slovenia & 97 & 98 & 33 & 8 & 72 & 2 & 76 \\
\hline Spain & 94 & 125 & 72 & 6 & 67 & 1 & 97 \\
\hline
\end{tabular}

PAGE 16| Journal of Corporate Governance, Insurance, and Risk Management | 2021, VOL. 8, Series. 2 


\begin{tabular}{|c|c|c|c|c|c|c|c|}
\hline Sweden & 99 & 39 & 19 & 1 & 28 & 2 & 52 \\
\hline Thailand & 77 & 104 & 11 & 2 & 55 & 1 & 64 \\
\hline Turkey & 60 & 71 & 18 & 2 & 82 & 7 & 50 \\
\hline Uganda & 27 & 4 & 2 & 4 & 56 & 6 & 11 \\
\hline Ukraine & 52 & 92 & 0.9 & 29 & 122 & 0.4 & 48 \\
\hline $\begin{array}{c}\text { United Arab } \\
\text { Emirate }\end{array}$ & 76 & 61 & 12 & 6 & 82 & 4 & 49 \\
\hline $\begin{array}{c}\text { Full sample } \\
\text { average }\end{array}$ & 65 & 69 & 21 & 6 & 81 & 3 & 52 \\
\hline Source: Authors' computation & & & & & & \\
\hline
\end{tabular}

The correlation analysis is reported in table 2. In the correlation analysis, LLP is positive and significantly correlated with NPL as expected. Interestingly, LLP is negatively correlated with the three financial inclusion variables. The ACC, BR and ATM variables have a negative and significant correlation with LLP. This suggests that higher financial inclusion (i.e., higher formal account ownership, bank branch supply and ATM supply) is associated with fewer loan loss provisions. Meanwhile, NPL is positive and significantly correlated with BR. This suggest that increase in bank branches is associated with higher non-performing loans. Finally, the correlation between the three financial inclusion variables (ACC, BR and ATM) is low. Therefore, multi-collinearity is not a problem in our analysis.

Table 2: Pearson correlation of the variables

\begin{tabular}{|c|c|c|c|c|c|c|c|}
\hline Variables & LLP & NPL & GDP & ACC & $\mathrm{BR}$ & ATM & AFI \\
\hline LLP & $\begin{array}{c}1.000 \\
---- \\
----\end{array}$ & & & & & & \\
\hline NPL & $\begin{array}{c}0.179 * * \\
(2.16) \\
((0.03))\end{array}$ & $\begin{array}{l}1.000 \\
----- \\
---\end{array}$ & & & & & \\
\hline GDP & $\begin{array}{c}-0.07 \\
(-0.83) \\
((0.40))\end{array}$ & $\begin{array}{c}-0.234^{* *} \\
(-2.85) \\
((0.00))\end{array}$ & $\begin{array}{c}1.000 \\
---- \\
----\end{array}$ & & & & \\
\hline ACC & $\begin{array}{c}-0.383^{* * *} \\
(-4.92) \\
((0.00))\end{array}$ & $\begin{array}{c}0.102 \\
(1.22) \\
((0.23))\end{array}$ & $\begin{array}{c}-0.306^{* * *} \\
(-3.82) \\
((0.00))\end{array}$ & $\begin{array}{l}1.000 \\
----- \\
-----\end{array}$ & & & \\
\hline $\mathrm{BR}$ & $\begin{array}{c}-0.165^{* *} \\
(-1.99) \\
((0.04))\end{array}$ & $\begin{array}{c}0.212^{* *} \\
(2.58) \\
((0.01))\end{array}$ & $\begin{array}{c}-0.271 * * * \\
(-3.33) \\
((0.00))\end{array}$ & $\begin{array}{c}0.272 * * * \\
(3.36) \\
((0.00))\end{array}$ & $\begin{array}{c}1.000 \\
----- \\
----\end{array}$ & & \\
\hline ATM & $\begin{array}{c}-0.199 * * \\
(-2.41) \\
((0.02))\end{array}$ & $\begin{array}{c}-0.003 \\
(-0.041) \\
((0.96))\end{array}$ & $\begin{array}{c}-0.295^{* * *} \\
(-3.67) \\
(0.00))\end{array}$ & $\begin{array}{c}0.559 * * * \\
(8.02) \\
((0.00))\end{array}$ & $\begin{array}{c}0.312^{* * * *} \\
(3.91) \\
((0.00))\end{array}$ & $\begin{array}{c}1.000 \\
---- \\
----\end{array}$ & \\
\hline
\end{tabular}




\begin{tabular}{l|ccccccc} 
& & & & & & \\
AFI & $-0.310^{* * *}$ & 0.082 & $-0.363^{* * *}$ & $0.801^{* * *}$ & $0.513^{* * *}$ & $0.916^{* * *}$ & 1.000 \\
& $(-3.87)$ & $(0.98)$ & $(-4.62)$ & $(15.91)$ & $(7.09)$ & $(27.23)$ & ----- \\
& $(0.00)$ & $((0.32))$ & $((0.00))$ & $((0.00))$ & $((0.00))$ & $((0.00))$ & ---- \\
\hline
\end{tabular}

Source: Authors' computation. ***, **, * denote significance at $1 \%, 5 \%$ and $10 \%$ levels. Numbers in double parenthesis are p-values. Numbers in single parenthesis are t-values

\subsection{Regression results}

\subsubsection{Effect of financial inclusion on loan loss provisions}

First, we examine the effect of the individual financial inclusion variables on loan loss provisions using a step-wise panel regression procedure. The result is reported in table 3. The ACC, BR and ATM coefficients are statistically insignificant in column 1, 2 and 3. The result suggests that each of the financial inclusion variables do not have a significant effect on loan loss provisions when they are examined separately.

Next, we introduce the three financial inclusion variables into the model and re-estimate the model. The result is reported in column 4. The ACC, BR and ATM coefficients are statistically insignificant in column 4. This indicates that the number of formal account ownership, bank branches and automated teller machines do not significantly affect the size of loan loss provisions when they are examined together.

Next, we introduce the financial inclusion index variable (AFI) as a proxy for financial inclusion, and examine its effect on loan loss provisions. The result is reported in column 5. The AFI coefficient is statistically insignificant. This suggest that financial inclusion has no significant effect on loan loss provisions.

Further, we perform some interaction analysis to determine whether the individual financial inclusion variables may have some effect on loan loss provisions when they are combined. The result is reported in column 6 and 7. The ACC*ATM coefficient is positive and significant in column 6 and 7. This suggests that loan loss provisions are higher in countries that have greater formal account ownership and greater ATM supply. Similarly, BR*ATM coefficient is positive and significant in column 6 and 7 . This suggest that loan loss provisions are higher in countries that have greater bank branch and greater ATM supply. Finally, the ACC*BR*ATM coefficient is negative and significant in column 7. This suggest that loan loss provisions are fewer in countries that have high levels of formal account ownership, bank branch supply and ATM supply. 
Table 3: Effect of financial inclusion on bank loan loss provisions

\begin{tabular}{|c|c|c|c|c|c|c|c|}
\hline \multicolumn{8}{|c|}{ Dependent variable: LLP } \\
\hline & \multicolumn{3}{|c|}{ Stepwise analysis } & \multirow{2}{*}{4} & \multirow{2}{*}{$\frac{\text { AFI index }}{5}$} & \multicolumn{2}{|c|}{ Interaction analysis } \\
\hline & 1 & 2 & 3 & & & 6 & 7 \\
\hline & $\begin{array}{l}\text { Coefficient } \\
\text { (t-statistic) }\end{array}$ & $\begin{array}{l}\text { Coefficient } \\
\text { (t-statistic) }\end{array}$ & $\begin{array}{l}\text { Coefficient } \\
\text { (t-statistic) }\end{array}$ & $\begin{array}{l}\text { Coefficient } \\
\text { (t-statistic) }\end{array}$ & $\begin{array}{l}\text { Coefficient } \\
\text { (t-statistic) }\end{array}$ & $\begin{array}{l}\text { Coefficient } \\
\text { (t-statistic) }\end{array}$ & $\begin{array}{l}\text { Coefficient } \\
\text { (t-statistic) }\end{array}$ \\
\hline C & $\begin{array}{c}62.383^{* * * *} \\
(4.39)\end{array}$ & $\begin{array}{c}68.242^{* * *} \\
(8.25)\end{array}$ & $\begin{array}{c}77.371^{* * *} \\
(9.23)\end{array}$ & $\begin{array}{c}68.429 * * * \\
(4.45)\end{array}$ & $\begin{array}{c}78.299 * * * \\
(6.04)\end{array}$ & $\begin{array}{c}78.112 * * * \\
(3.73)\end{array}$ & $\begin{array}{c}95.514^{* * *} \\
(4.13)\end{array}$ \\
\hline ACC & $\begin{array}{l}0.049 \\
(0.24) \\
\end{array}$ & & & $\begin{array}{l}0.137 \\
(0.62) \\
\end{array}$ & & $\begin{array}{c}0.197 \\
(0.60) \\
\end{array}$ & $\begin{array}{l}-0.066 \\
(-0.18) \\
\end{array}$ \\
\hline $\mathrm{BR}$ & & $\begin{array}{l}-0.101 \\
(-0.31)\end{array}$ & & $\begin{array}{l}0.090 \\
(0.25)\end{array}$ & & $\begin{array}{l}0.130 \\
(0.18)\end{array}$ & $\begin{array}{l}-1.156 \\
(-1.13) \\
\end{array}$ \\
\hline ATM & & & $\begin{array}{l}-0.155 \\
(-1.44)\end{array}$ & $\begin{array}{l}-0.187 \\
(-1.52)\end{array}$ & & $\begin{array}{c}-0.811 * * * \\
(-2.99)\end{array}$ & $\begin{array}{c}-1287 * * * \\
(-3.34)\end{array}$ \\
\hline AFI & & & & & $\begin{array}{l}-0.229 \\
(-0.99) \\
\end{array}$ & & \\
\hline NPL & $\begin{array}{c}1.413^{* * *} \\
(5.69)\end{array}$ & $\begin{array}{c}1.419 * * * \\
(5.88)\end{array}$ & $\begin{array}{c}1.471^{* * *} \\
(6.36)\end{array}$ & $\begin{array}{c}1.382^{* * *} \\
(5.50)\end{array}$ & $\begin{array}{c}1.436 * * * \\
(5.97)\end{array}$ & $\begin{array}{c}1.305^{* * *} \\
(5.25)\end{array}$ & $\begin{array}{c}1.302^{* * *} \\
(5.29)\end{array}$ \\
\hline GDP & $\begin{array}{c}1.627 * * * \\
(2.77)\end{array}$ & $\begin{array}{c}1.543 * * * \\
(2.72)\end{array}$ & $\begin{array}{c}1.386^{* *} \\
(2.46)\end{array}$ & $\begin{array}{c}1.504^{* *} \\
(2.52)\end{array}$ & $\begin{array}{c}1.392^{* *} \\
(2.37) \\
\end{array}$ & $\begin{array}{c}1.687 * * * \\
(2.84)\end{array}$ & $\begin{array}{c}1.718^{* * * *} \\
(2.93)\end{array}$ \\
\hline ACC*ATM & & & & & & $\begin{array}{c}0.006^{* *} \\
(2.03)\end{array}$ & $\begin{array}{c}0.012^{* *} \\
(2.64)\end{array}$ \\
\hline $\mathrm{ACC} * \mathrm{BR}$ & & & & & & $\begin{array}{l}-0.011 \\
(-1.15)\end{array}$ & $\begin{array}{l}0.006 \\
(0.43) \\
\end{array}$ \\
\hline BR*ATM & & & & & & $\begin{array}{l}0.008^{*} \\
(1.65)\end{array}$ & $\begin{array}{c}0.035^{* *} \\
(2.11) \\
\end{array}$ \\
\hline ACC*BR*ATM & & & & & & & $\begin{array}{c}-0.0003^{*} \\
(-1.72) \\
\end{array}$ \\
\hline $\mathrm{R}^{2}$ & 94.51 & 94.52 & 94.63 & 94.66 & 94.57 & 95.08 & 95.25 \\
\hline Adjusted $\mathrm{R}^{2}$ & 91.34 & 91.39 & 91.57 & 91.38 & 91.43 & 91.79 & 91.97 \\
\hline F-statistic & 29.81 & 30.17 & 30.87 & 28.88 & 30.13 & 28.85 & 29.05 \\
\hline
\end{tabular}

\subsubsection{Transient effect of financial inclusion on loan loss provisions}

In this section, we investigate the transient effect of each financial inclusion variable on loan loss provisions. To do this, we interact each financial inclusion variable on each control variable in order to determine their transient effect. The result is reported in table 4.

The ATM*NPL coefficient is positive and significant. This suggest that loan loss provisions are higher in countries that have high ATM supply and high non-performing loans. The result implies that higher ATM supply (or high financial inclusion) did not dampen the effect of non-performing loans on the size of loan loss provisions. Meanwhile, the ACC*NPL, ACC*GDP, BR*NPL, AFI*NPL, AFI*GDP, $\mathrm{BR} * \mathrm{GDP}$ and $\mathrm{ATM}{ }^{*} \mathrm{GDP}$ coefficients are insignificant.

PAGE 19| Journal of Corporate Governance, Insurance, and Risk Management | 2021, VOL. 8, Series. 2 
Table 4: Effect of financial inclusion on loan loss provisions: transient effect

\begin{tabular}{|c|c|c|c|c|}
\hline \multicolumn{5}{|c|}{ Dependent variable: LLP } \\
\hline & $\begin{array}{l}\text { Coefficient } \\
\text { (t-statistic) }\end{array}$ & $\begin{array}{l}\text { Coefficient } \\
\text { (t-statistic) }\end{array}$ & $\begin{array}{l}\text { Coefficient } \\
\text { (t-statistic) }\end{array}$ & $\begin{array}{l}\text { Coefficient } \\
\text { (t-statistic) }\end{array}$ \\
\hline c & $\begin{array}{c}51.810^{* * *} \\
(2.74)\end{array}$ & $\begin{array}{c}70.499 * * * \\
(4.57)\end{array}$ & $\begin{array}{c}74.185^{* * *} \\
(4.71) \\
\end{array}$ & $\begin{array}{c}78.880 * * * \\
(4.97)\end{array}$ \\
\hline ACC & $\begin{array}{r}0.389 \\
(1.42) \\
\end{array}$ & $\begin{array}{c}0.101 \\
(0.46) \\
\end{array}$ & $\begin{array}{r}0.203 \\
(0.95) \\
\end{array}$ & \\
\hline BR & & $\begin{array}{l}0.239 \\
(0.63)\end{array}$ & $\begin{array}{l}-0.048 \\
(-0.13)\end{array}$ & \\
\hline ATM & & & $\begin{array}{c}-0.288 * * \\
(-2.13)\end{array}$ & \\
\hline AFI & & & & $\begin{array}{l}-0.244 \\
(-0.87) \\
\end{array}$ \\
\hline NPL & $\begin{array}{c}3.013 * * \\
(2.23)\end{array}$ & $\begin{array}{c}1.763^{* * *} \\
(4.99)\end{array}$ & $\begin{array}{l}-0.220 \\
(-0.32)\end{array}$ & $\begin{array}{l}0.629 \\
(0.37)\end{array}$ \\
\hline GDP & $\begin{array}{c}3.442^{* *} \\
(2.02)\end{array}$ & $\begin{array}{c}1.614^{*} \\
(1.80)\end{array}$ & $\begin{array}{c}2.743^{* *} \\
(2.14)\end{array}$ & $\begin{array}{l}2.569 \\
(1.55)\end{array}$ \\
\hline ACC*NPL & $\begin{array}{l}-0.021 \\
(-1.22)\end{array}$ & & & \\
\hline ACC*GDP & $\begin{array}{l}-0.029 \\
(-1.14) \\
\end{array}$ & & & \\
\hline $\mathrm{BR} * \mathrm{NPL}$ & & $\begin{array}{l}-0.019 \\
(-1.48) \\
\end{array}$ & & \\
\hline $\mathrm{BR} * \mathrm{GDP}$ & & $\begin{array}{l}-0.007 \\
(-0.19) \\
\end{array}$ & & \\
\hline ATM*NPL & & & $\begin{array}{c}0.022^{* *} \\
(2.48)\end{array}$ & \\
\hline ATM*GDP & & & $\begin{array}{l}-0.017 \\
(-1.03)\end{array}$ & \\
\hline AFI*NPL & & & & $\begin{array}{l}0.015 \\
(0.50)\end{array}$ \\
\hline AFI*GDP & & & & $\begin{array}{l}-0.025 \\
(-0.78) \\
\end{array}$ \\
\hline $\mathrm{R}^{2}$ & 94.81 & 94.91 & 95.10 & 94.64 \\
\hline Adjusted $\mathrm{R}^{2}$ & 91.43 & 91.42 & 91.91 & 91.36 \\
\hline F-statistic & 28.04 & 28.03 & 29.82 & 28.79 \\
\hline $\begin{array}{l}\text { Source: Autho } \\
\text { and } 10 \% \text { level }\end{array}$ & computatic & $\begin{array}{l}* * *, * *, * c \\
\text { enthesis ar }\end{array}$ & $\begin{array}{l}\text { e significan } \\
\text { atistic value }\end{array}$ & t 1\%, 5\% \\
\hline
\end{tabular}

\subsubsection{Effect of financial inclusion on non-performing loans}

In this section, we examine the effect of the individual financial inclusion variables on non-performing loans. The result in column 1 of table 5 show that the ACC coefficient is positive and significant. This suggest that greater formal account ownership is associated with higher non-performing loans. This implies that as more people own formal accounts, non-performing loans are likely to increase. The BR and ATM coefficients are statistically insignificant in column 1. This indicates that the number of bank branch and automated teller machines do not significantly affect the size of non-performing loans.

PAGE 20| Journal of Corporate Governance, Insurance, and Risk Management | 2021, VOL. 8, Series. 2 
Further, we perform some interaction analysis to determine whether the individual financial inclusion variables have some joint effect, and transient effect, on non-performing loans. The result is reported in column 2 and 3. The ACC*ATM*GDP coefficient is positive and significant. The result suggests that greater formal account ownership, ATM supply and economic prosperity jointly increase nonperforming loans rather than reduce it. Similarly, ACC*BR*GDP coefficient is positive and significant. The result suggests that greater formal account ownership, increase in branch supply and economic prosperity jointly increase non-performing loans rather than reduce it. The ACC*BR*ATM*GDP coefficient is negative and significant. This implies that non-performing loans are fewer in countries that experience economic boom and high levels of financial inclusion which is achieved through the combined use of greater formal account ownership, increase in bank branch supply and greater ATM supply.

Table 5: Effect of financial inclusion on non-performing loans

\begin{tabular}{|c|c|c|c|c|}
\hline \multicolumn{5}{|c|}{ Dependent variable: NPL } \\
\hline & 1 & 2 & 3 & 4 \\
\hline & $\begin{array}{l}\text { Coefficient } \\
\text { (t-statistic) }\end{array}$ & $\begin{array}{l}\text { Coefficient } \\
\text { (t-statistic) }\end{array}$ & $\begin{array}{l}\text { Coefficient } \\
\text { (t-statistic) }\end{array}$ & $\begin{array}{l}\text { Coefficient } \\
\text { (t-statistic) }\end{array}$ \\
\hline c & $\begin{array}{l}-4.246 \\
(-0.66)\end{array}$ & $\begin{array}{l}-4.974 \\
(-0.63)\end{array}$ & $\begin{array}{l}5.635 \\
(0.73)\end{array}$ & $\begin{array}{l}5.490 \\
(0.95)\end{array}$ \\
\hline ACC & $\begin{array}{c}0.229 * * \\
(2.57)\end{array}$ & $\begin{array}{c}0.238 * * \\
(2.11)\end{array}$ & $\begin{array}{l}0.154 \\
(1.55)\end{array}$ & \\
\hline $\mathrm{BR}$ & $\begin{array}{l}-0.193 \\
(-1.26)\end{array}$ & $\begin{array}{l}-0.188 \\
(-1.20)\end{array}$ & $\begin{array}{c}-0.454^{* *} \\
(-2.56)\end{array}$ & \\
\hline ATM & $\begin{array}{l}-0.022 \\
(-0.42)\end{array}$ & $\begin{array}{l}-0.019 \\
(-0.35)\end{array}$ & $\begin{array}{l}-0.003 \\
(-0.05)\end{array}$ & \\
\hline AFI & & & & $\begin{array}{l}-0.004 \\
(-0.04)\end{array}$ \\
\hline GDP & $\begin{array}{c}0.567^{* *} \\
(2.32) \\
\end{array}$ & $\begin{array}{l}0.170 \\
(0.23)\end{array}$ & $\begin{array}{l}-0.755 \\
(-1.29) \\
\end{array}$ & $\begin{array}{l}-0.418 \\
(-0.62) \\
\end{array}$ \\
\hline ACC*GDP & & $\begin{array}{l}-0.004 \\
(-0.26)\end{array}$ & & \\
\hline $\mathrm{BR} * \mathrm{GDP}$ & - & $\begin{array}{l}0.017 \\
(1.01)\end{array}$ & & \\
\hline ATM*GDP & & $\begin{array}{l}0.005 \\
(0.49)\end{array}$ & & \\
\hline ACC*ATM*GDP & & & $\begin{array}{c}0.0002 * \\
(1.79)\end{array}$ & \\
\hline $\mathrm{ACC} * \mathrm{BR} * \mathrm{GDP}$ & & & $\begin{array}{c}0.001 * * * \\
(2.72)\end{array}$ & \\
\hline BR*ATM*GDP & & & $\begin{array}{l}0.001 \\
(1.14)\end{array}$ & \\
\hline ACC*BR*ATM*GDP & & & $\begin{array}{c}-0.0002^{* *} \\
(-2.57)\end{array}$ & \\
\hline $\mathrm{AFI}^{*} \mathrm{GDP}$ & & & & $\begin{array}{l}0.019 \\
(1.51) \\
\end{array}$ \\
\hline $\mathrm{R}^{2}$ & 78.83 & 79.17 & 80.92 & 77.53 \\
\hline
\end{tabular}




\begin{tabular}{|c|c|c|c|c|}
\hline Adjusted $\mathrm{R}^{2}$ & 66.22 & 65.60 & 68.12 & 64.56 \\
\hline F-statistic & 6.25 & 5.84 & 6.32 & 5.97 \\
\hline Source: Authors' computation. & $* * *, * *, *$ denote significance at $1 \%, 5 \%$ and \\
10\% levels. Numbers in parenthesis are t-statistic values.
\end{tabular}

\section{CONCLUSION}

This paper examined the impact of financial inclusion on bank non-performing loans and loan loss provisions. The result showed that greater formal account ownership is associated with high nonperforming loans. Also, loan loss provisions are lower in countries that have high levels of financial inclusion. Furthermore, non-performing loans are fewer in countries that experience economic boom and high levels of financial inclusion which is achieved through the combined use of greater formal account ownership, increase in bank branch supply and greater ATM supply.

The findings have policy implications. Policy makers should focus on further improvement in financial inclusion in good times because it has positive benefits for bank non-performing loans and loan loss provisions. Policy makers in several countries should strive to promote formal account ownership, availability of bank branches and ATM supply not only to reduce the level of financial exclusion but also to complement existing macro prudential policies towards enhancing bank stability. The main limitation of the study is that the sample period is narrow. This is because the World Bank's financial inclusion data often have a short time span. Future studies can examine the effect of financial inclusion on bank's risk-taking. Future studies can also explore the impact of financial inclusion on other indicators of bank stability other than non-performing loans and loan loss provisions such as capital adequacy ratio and insolvency risk.

\section{REFERENCE}

Ahamed, M. M., \& Mallick, S. K. (2019). Is financial inclusion good for bank stability? International evidence. Journal of Economic Behavior \& Organization, 157, 403-427.

Bhat, G., Ryan, S. G., \& Vyas, D. (2019). The implications of credit risk modeling for banks' loan loss provisions and loan-origination procyclicality. Management Science, 65(5), 2116-2141.

Boudriga, A., Taktak, N. B., \& Jellouli, S. (2009). Banking supervision and nonperforming loans: a cross-country analysis. Journal of financial economic policy, 1(4), 286-318.

Caporale, G. M., Alessi, M., Di Colli, S., \& Lopez, J. S. (2018). Loan loss provisions and macroeconomic shocks: Some empirical evidence for italian banks during the crisis. Finance Research Letters, 25, 239-243.

Chauvet, L., \& Jacolin, L. (2017). Financial inclusion, bank concentration, and firm performance. World Development, 97, 1-13.

Chen, F. W., Feng, Y., \& Wang, W. (2018). Impacts of financial inclusion on non-performing loans of commercial banks: Evidence from China. Sustainability, 10(9), 3084.

Danisman, G. O., Demir, E., \& Ozili, P. (2021). Loan loss provisioning of US banks: Economic policy uncertainty and discretionary behavior. International Review of Economics \& Finance, 71, 923935.

Emara, N., \& El Said, A. (2021). Financial inclusion and economic growth: The role of governance in selected MENA countries. International Review of Economics \& Finance, 75, 34-54 
Floro, D. (2010). Loan loss provisioning and the business cycle: Does capital matter? Evidence from Philippine banks. BIS Research Paper, 1-36.

García, M. J. R., \& José, M. (2016). Can financial inclusion and financial stability go hand in hand. Economic Issues, 21(2), 81-103.

Han, R., \& Melecky, M. (2013). Financial inclusion for financial stability: Access to bank deposits and the growth of deposits in the global financial crisis. The World Bank. World Bank Policy Research Working Paper No. 6577

Hannig, A., \& Jansen, S. (2010). Financial inclusion and financial stability: Current policy issues. ADBI Working Paper No. 259

Kumar, V., Thrikawala, S., \& Acharya, S. (2021). Financial inclusion and bank profitability: Evidence from a developed market. Global Finance Journal, 100609, (forthcoming, in press)

Léon, F., \& Zins, A. (2020). Regional foreign banks and financial inclusion: Evidence from Africa. Economic Modelling, 84, 102-116.

Markose, S., Arun, T., \& Ozili, P. (2020). Financial inclusion, at what cost? Quantification of economic viability of a supply side roll out. The European Journal of Finance (https://www.tandfonline.com/doi/abs/10.1080/1351847X.2020.1821740)

Morgan, P., \& Pontines, V. (2014). Financial stability and financial inclusion. ADBI Working Paper 488.

Musau, S., Muathe, S., \& Mwangi, L. (2018). Financial inclusion, bank competitiveness and credit risk of commercial banks in Kenya. International Journal of Financial Research, 9(1), 203-218.

Muthia, F., Raneo, A. P., \& Andaiyani, S. (2019). Financial Inclusion and Bank Efficiency in Indonesia. J. Advanced Res. L. \& Econ., 10, 595.

Naumenkova, S., Mishchenko, S., \& Dorofeiev, D. (2019). Digital financial inclusion: Evidence from Ukraine. Investment Management and Financial Innovations, 16(3), 194-205.

Neaime, S., \& Gaysset, I. (2018). Financial inclusion and stability in MENA: Evidence from poverty and inequality. Finance Research Letters, 24, 230-237.

Nkusu, M. (2011). Nonperforming loans and macrofinancial vulnerabilities in advanced economies. IMF Working Paper 11/161, 1-27.

Owen, A. L., \& Pereira, J. M. (2018). Bank concentration, competition, and financial inclusion. Review of development finance, 8(1), 1-17.

Ozili, P. K. (2017). Bank earnings smoothing, audit quality and procyclicality in Africa: the case of loan loss provisions. Review of Accounting and Finance, 16(2), 142-161.

Ozili, P. K., \& Outa, E. (2017). Bank loan loss provisions research: A review. Borsa Istanbul Review, 17(3), 144-163.

Ozili, P. K. (2018). Impact of digital finance on financial inclusion and stability. Borsa Istanbul Review, 18(4), 329-340.

Ozili, P. K. (2020, January). Financial inclusion research around the world: A review. In Forum for social economics (pp. 1-23). Routledge.

Ozili, P. K. (2021a) Has financial inclusion made the financial sector riskier? Journal of Financial Regulation and Compliance, 29, 3, 237-255.

Ozili, P. K. (2021b). Financial inclusion in Nigeria: an overview. International Journal of Banking and Finance, Forthcoming.

Ozili, P. K. (2021c). Banking sector earnings management using loan loss provisions in the Fintech era. International Journal of Managerial (https://www.emerald.com/insight/content/doi/10.1108/IJMF-07-2020-0369/full/html) (forthcoming)

Peterson, O. K., \& Arun, T. G. (2018). Income smoothing among European systemic and non-systemic banks. The British Accounting Review, 50(5), 539-558.

Pool, S., De Haan, L., \& Jacobs, J. P. (2015). Loan loss provisioning, bank credit and the real economy. Journal of Macroeconomics, 45, 124-136.

Raza, M. S., Tang, J., Rubab, S., \& Wen, X. (2019). Determining the nexus between financial inclusion and economic development in Pakistan. Journal of Money Laundering Control, 22 (2), 195-209.

Subbarao, D. (2009). Financial inclusion: Challenges and opportunities. Financial inclusion: Challenges and opportunities. BIS Review, 163, 1-8. 
Appendix

A1: Variable description and sources

\begin{tabular}{|l|l|l|}
\hline \multicolumn{1}{|c|}{ Variable description / definition } & Symbol & \multicolumn{1}{c|}{ Source } \\
\hline Account at a formal financial institution (\% age 15+) & ACC & $\begin{array}{l}\text { Global financial development } \\
\text { indicators }\end{array}$ \\
\hline ATMs per 100,000 adults & ATM & $\begin{array}{l}\text { Global financial development } \\
\text { indicators }\end{array}$ \\
\hline Bank branches per 100,000 adults & BR & $\begin{array}{l}\text { Global financial development } \\
\text { indicators }\end{array}$ \\
\hline $\begin{array}{l}\text { Financial inclusion index (average of sum of ACC, BR and } \\
\text { ATM) }\end{array}$ & AFI & Author's computation \\
\hline Bank non-performing loans to gross loans ratio (\%) & NPL & $\begin{array}{l}\text { Global financial development } \\
\text { indicators }\end{array}$ \\
\hline Provisions to non-performing loans ratio (\%) & LLC & $\begin{array}{l}\text { Global financial development } \\
\text { indicators }\end{array}$ \\
\hline $\begin{array}{l}\text { Loan loss Provisions to gross loans ratio (\%) derived by } \\
\text { multiplying NPL ratio with LLC ratio }\end{array}$ & LLP & Author's computation \\
\hline Real GDP growth rate & GDP & World development indicators \\
\hline
\end{tabular}

